Cybernetics: Journal Educational Research and Social Studies

Volume 2, Nomor 3, Juli 2021

Journal Homepage: http://pusdikra-publishing.com/index.php/jrss

\title{
Pemahaman Konsep Bentuk Aljabar Dan Kaitannya Dengan Hasil Belajar Matematika Pada Siswa Kelas VII MTsN 2 Medan Tahun Pelajaran 2019/2020
}

\section{Lailatun Nur Kamalia Siregar}

Universitas Islam Negeri Sumatera Utara

Corresponding Author : $\otimes$

\begin{tabular}{|c|c|}
\hline & ABSTRACT \\
\hline & $\begin{array}{l}\text { Tujuan penelitian ini adalah untuk mengetahui : (1) Bagaimana pemahaman } \\
\text { konsep operasi bentuk aljabar di kelas VII MTsN } 2 \text { Medan Tahun Pelajaran } \\
2019 / 2020 \text {, (2) Bagaimana hasil belajar matematika siswa di kelas VII MTsN } 2 \\
\text { Medan Tahun Pelajaran } 2019 / 2020 \text {, (3) Bagaimana hubungannya antara } \\
\text { pemahaman konsep operasi bentuk aljabar dengan hasil belajar matematika } \\
\text { siswa di kelas VII MTsN } 2 \text { Medan Tahun Pelajaran } 2019 / 2020 \text {. Penelitian ini } \\
\text { merupakan penelitian menggunakan metode dekripsi Kuantitatif. Populasi } \\
\text { dalam penelitian ini adalah siswa/I kelas VII MTsN } 2 \text { Medan Tahun Pelajaran } \\
2019 / 2020 \text {. Populasi dalam penelitian ini berjumlah } 360 \text { orang siswa/I kelas VII } \\
\text { MTsN } 2 \text { Medan Tahun Pelajaran } 2019 / 2020 \text { sedangkan sampel dalam penelitian } \\
\text { ini mengambil sebesar } 20 \% \text { dari jumlah populasi yaitu } 78 \text { orang siswa/i. } \\
\text { Intrumen pengumpulan data dalam penelitian ini adalah tes. Berdasarkan hasil } \\
\text { penelitian, diperoleh kedua variabel penelitian berdistribusi normal. Untuk } \\
\text { variabel pemahaman konsep bentuk aljabar }(X) \text { diperoleh } x^{2} \text { hitung }=-252,11 \text { dan } \\
\text { variabel hasil belajar matematika siswa }(Y) \text { diperoleh } x^{2} \text { hitung }=-13625,02 \text {, } \\
\text { sedangkan } x^{2} \text { tabel pada taraf signifikan } a=5 \% \text { adalah sebesar } 11,070 \text {. Sehingga } \\
\text { untuk kedua variabel penelitian diperoleh } x^{2} \text { hitung }>x^{2} \text { tabel dan ini berarti bahwa } \\
\text { kedua variabel penelitian adalah berdistribusi normal. Dalam penelitian ini juga } \\
\text { diperoleh koefisien korelasi } r_{x y}=0,974 \text {, sedangkan } t \text { hitung }=37,48 \text {. Nilai } t \text { tabel }(\mathrm{dk} \\
76: a=0,05) \text { adalah sebesar } 1,995 \text { sehingga diperoleh } t \text { hitung }=37,48>t \text { tabel }=1,995 . \\
\text { Sedangkan koefisien determinan I }=0,94 \text { atau } 94 \% \text { yang berarti besarnya } \\
\text { sumbangan variabel bebas } X \text { terhadap variabel terikat } Y \text { adalah } 94 \% \text { sedangkan } \\
6 \% \text { lagi ditentukan oleh faktor lain. Jadi yang menjadi kesimpulan dalam } \\
\text { penelitian ini adalah : ada hubungan antara pemahaman konsep bentuk aljabar } \\
\text { dengan hasil belajar matematika siswa kelas VII MTsN } 2 \text { Medan. }\end{array}$ \\
\hline Kata Kunci & Pemahaman, Konsep, Hasil Belajar, Siswa \\
\hline
\end{tabular}

\section{PENDAHULUAN}

Pendidikan adalah proses pengubahan sikap dan tata laku seseorang atau kelompok orang dalam usaha mendewasakan manusia melalui upaya pelajaran dan pelatihan. Pendidikan mempunyai peranan yang sangat menentukan bagi perkembangan dan perwujudan diri individu, terutama bagi perkembangan bangsa dan negara. Kemajuan suatu kebudayaan bergantung kepada cara kebudayaan tersebut mengenali, menghargai, dan memanfaatkan sumber daya manusia. Hal ini berkaitan erat dengan kualitas pendidikan yang diberikan kepada anggota masyarakat dan kepada peserta didiknya. 
Dari kedua tujuan pendidikan di atas, dapat disimpulkan bahwa proses pendidikan yang ideal adalah proses pendidikan yang dikemas dengan memperhatikan adanya sebagai aspek, yaitu aspek kognitif, afektif, dan psikomotorik. Apabila proses pendidikan dapat dilaksanakan dengan memperhatikan adanya keseimbangan ketiga aspek tersebut, maka pendidikan akan mampu mengantisipasi perubahan dan kemajuan masyarakat.

Matematika merupakan salah satu ilmu pengetahuan yang paling penting dalam pengembangan proses pendidikan. Ilmu-ilmu pengetahuan lainnya tidak akan berjalan dengan sempurna, karena matematika dapat mengembangkan dirinya mencapai keberhasilan. Namun pada kenyataannya, masalah yang sering muncul adalah kemampuan siswa dalam pemahaman konsep matematika masih rendah. Siswa beranggapan bahwa matematika hanyalah kumpulan angka-angka yang sulit dipahami. Selain rendahnya hasil belajar matematika dan perhatian siswa pada pelajaran matematika juga dapat menghambat siswa untuk memahami materi yang mereka pelajari.

Dalam belajar bentuk aljabar khususnya operasi bentuk aljabar, kesulitan yang sering dialami siswa dan cenderung membuat siswa merasa bosan, bisa jadi disebabkan oleh beberapa hal diantaranya : metode mengajar yang kurang tepat, suasana belajar yang menantang untuk membangun imajinasi anak, dan guru kurang memotivasi kemampuan abstraksi anak. Karena hal tersebut, nilai matematika siswa dari tahun ke tahun selalu rendah jika dibandingkan dengan pelajaran yang lain seperti pelajaran Bahasa Indonesia, Bahasa Inggris dan Agama.

Belajar juga mendapatkan suatu proses internal dan kondisi lingkungan luar yang essensial bagi berbagai macam hasil belajar dan keterampilan, terutama belajar matematika. Faktor-faktor yang mempengaruhi belajar matematika adalah faktor yang mempengaruhi belajar kognitif disamping pengetahuan umum, kemampuan penalaran deduktif dan kemampuan keterampilan.

Berdasarkan penyataan tersebut dapat disimpulkan bahwa struktur mental itu bukan hanya menerima informasi baru. Asimilasi dan Akomodasi merupakan dua aspek yang sama dari proses yang sama. Kedua aspek itu adalah dua aspek dari aktifitas intelektual yang dasarnya adalah suatu proses yang melibatkan interaksi antara pikiran dan kenyataan serta kemampuankemampuan siswa dari hasil pelajaran, ada 3 tujuan pendidikan yang mendasar, yaitu 1) Tujuan kognitif berkenaan dengan tingkah laku dari perubahan berbagai proses mental, 2) Tujuan efektif berkenaan dengan perubahan tingkah laku dalam sikap, dan 3) Tujuan psikomotorik berkenaan dengan kemampuan memanipulasi secara fisik. 
Cybernetics: Journal of Research and Educational Studies

Volume 2 Nomor 3, Juli 2021

Halaman 84-93

Berdasarkan uraian pada latar belakang masalah, penelitian mengidentifikasi berbagai masalah sebagai berikut : Hasil belajar matematika siswa masih renda, Kemampuan siswa dalam penguasaan konsep matematika masih rendah, Metode yang digunakan guru dalam mengajar tidak bervariasi, Siswa menganggap matematika merupakan pelajaran yang sulit, Kurangnya motivasi guru kepada siswa.

Sehubungan dengan batasan masalah di atas, maka yang menjadi rumusan masalah dalam penelitian ini adalah sebagai berikut : Bagaimana pemahaman konsep bentuk Persegi Panjang di kelas VII MTsN 2 Medan Tahun Pelajaran 2019/2020, Bagaimana hasil belajar matematika siswa di kelas VII MTsN 2 Medan Tahun Pelajaran 2019/2020, Bagaimana hubungannya antara pemahaman konsep bentuk persegi panjang dengan hasil belajar matematika siswa di kelas VII MTsN 2 Medan Tahun Pelajaran 2019/2020.

Adapun tujuan penelitian ini adalah sebagai berikut : Untuk mengetahui pemahaman konsep bentuk persegi panjang di kelas VII MTsN 2 Medan Tahun Pelajaran 2019/2020. Untuk mengetahui hasil belajar matematika siswa di kelas VII MTsN 2 Medan Tahun Pelajaran 2019/2020. Untuk mengetahui hubungannya antara pemahaman konsep bentuk persegi panjang dengan hasil belajar matematika siswa di kelas VII MTsN 2 Medan Tahun Pelajaran 2019/2020.

Adapun manfaat dari penelitian ini adalah :

Manfaat Teoritis : Manfaat teoritis penelitian ini adalah memberikan masukan pengetahuan tentang pemahaman konsep bentuk aljabar dan kaitannya dengan hasil belajar matematika pada siswa.

Manfaat Paktis : Sebagai bahan masukan bagi kepala sekolah terutama VII MTsN 2 Medan untuk bisa mengingatkan hasil belajar siswa, Sebagai bahan masukan bagi guru dan orang tua dalam memberikan motivasi yang maksimal tentang belajar matematika, Sebagai bahan masukan bagi siswa yang mengalami kesulitan belajar khususnya belajar matematika, Sebagai bahan masukan bagi penelitian dan pembaca dalam mengembangkan wawasan dan ilmu pengetahuan dalam bidang pendidikan.

\section{METODE PENELITIAN}

Jenis penelitian yang digunakan adalah studi literatur. Metode studi literatur adalah serangkaian kegiatan yang berkenaan dengan metode pengumpulan data pustaka, membaca dan mencatat, serta mengelolah bahan penelitian (Zed, 2008:3). Studi kepustakaan merupakan kegiatan yang diwajibkan dalam penelitian, khususnya penelitian akademik yang tujuan utamanya adalah mengembangkan aspek teoritis maupun aspek manfaat 
praktis. Studi kepustakaan dilakukan oleh setiap peneliti dengan tujuan utama yaitu mencari dasar pijakan / fondasi utnuk memperoleh dan membangun landasan teori, kerangka berpikir, dan menentukandugaan sementara atau disebut juga dengan hipotesis penelitian. Sehingga para penelitidapat menggelompokkan, mengalokasikan mengorganisasikan, dan menggunakan variasi pustaka dalam bidangnya. Dengan melakukan studi kepustakaan, para peneliti mempunyai pendalaman yang lebih luas dan mendalam terhadap masalah yang hendak diteliti. Melakukan studi literatur ini dilakukan oleh peneliti antara setelah mereka menentukan topik penelitian dan ditetapkannya rumusan permasalahan, sebelum mereka terjun ke lapangan untuk mengumpulkan data yang diperlukan (Darmadi, 2011)

\section{HASIL DAN PEMBAHASAN}

\section{a. Pengertian Pemahaman Konsep}

Pemahaman menurut Kamus Besar Indonesia berarti "Proses, Perbuatan, Cara memahami atau memahamkan". Sudjono (2003 : 50) menyatakan bahwa "Pemahaman (Comprehension) adalah kemampuan seseorang untuk mengerti atau memahami sesuatu setelah sesuatu itu diketahui dan di ingat. Dengan kata lain memahami adalah mengetahui tentang sesuatu dan dapat melihatnya dari berbagai segi". "Pemahaman atau komprehensi adalah tingkat kemampuan yang mengharapkan siswa mampu memahami arti dalam konsep, situasi serta fakta yang diketahuinya. Dalam hal ini tes tidak hanya menghafal secara verbalitas, tapi memahami konsep dari masalah atau fakta yang dinyatakan".

Pemahaman adalah mencakup kemampuan untuk menangkap makna dan arti dari bahan yang dipelajari. Adanya kemampuan ini dinyatakan dalam menguraian isi pokok dari suatu bacaan, mengubah data yang disajikan dalam bentuk tertentu ke bentuk lain seperti rumus matematika ke dalam bentuk katakata, membuat perkiraan tentang kecenderungan yang nampak dalam data tertentu seperti dalam grafik. Pemahaman yaitu taraf ini mencakup bentuk pengertian yang paling rendah, taraf ini berlangsung dengan sejenis pemahaman yang menunjukkan bahwa siswa mengetahui apa yang sedang dikomunikasikan dan dapat digunakan bahan pengetahuan atau ide tertentu tanpa perlu menghubungkannya dengan bahan lain tanpa perlu melihat seluruh implikasinya.

Pemahaman dapat dibedakan ke dalam tiga kategoti yaitu :

Tingkat terendah adalah pemahaman terjemahan, mulai dari terjemahan dalam arti sebenarnya, misalnya dari bahasa Inggris ke dalam bahasa Indonesia, mengartikan Bhineka Tunggal Ika, mengartikan Merah putih, menerapkan prinsip-prinsip listrik dalam memasang sakelar. 
Cybernetics: Journal of Research and Educational Studies

Volume 2 Nomor 3, Juli 2021

Halaman 84-93

Tingkat kedua adalah pemahaman penafsiran, yakni menghubungkan bagian-bagian terdahulu yang diketahui berikutnya, atau menghubungkan beberapa bagian dari grafik dengan kejadian, membedakan yang pokok yang bukan pokok. Menghubungkan pengetahuan tentang konjungsi kata kerja, subjek dan possesive pronoun sehingga menyusun kalimat "My friend is studying", bukan My friend studying", merupakan contoh pemahaman penafsiran.

Pemahaman tingkat ketiga atau tingkat tertinggi adalah pemahaman ekstrapolasi. Dengan ekstrapolasi diharapkan seseorang mampu melihat di balik yang tertulis, dapat membuat ramalan tentang konsekuensi atau dapat memperluas presepsi dalam arti waktu, dimensi, kasus, ataupun masalahnya.

Pemahaman adalah suatu dasar bagi segala tindakan seseorang. Ia memberikan kontribusi yang besar bagi sukses tidaknya seseorang lebih jauh, pemahaman menjadikan seseorang saling mengerti, dan lebih lanjut lagi saling menghargai. Pemahaman sekaligus mencegah timbulnya saling curiga dan lebih jauh lagi mencegah timbulnya saling bentrokan.

Agar pemahaman akan konsep-konsep matematika dapat dipahami oleh anak-anak lebih mendasar harus diadakan pendekatan belajar dalam mengajar, antara lain :

1. Anak/peserta didik yang belajar matematika harus menggunakan benda-benda kongkrit dan membuat abstraksinya dari konsepkonsepnya.

2. Materi atau pelajaran yang akan diajarkan harus ada hubungannya atau pengaitan dengan yang sudah dipelajari.

3. Supaya anak/peserta didik memperoleh sesuatu dari belajar matematika harus mengubah suasana abstrak dengan menggunakan simbol.

4. Matematika adalah ilmu seni kreatif karena itu baru dipelajari dan diajarkan sebagai ilmu seni.

Dari kutipan di atas dapat disimpulkan bahwa pemahaman adalah proses sesuatu setelah sesuatu itu diketahui dan diingatnya, abstraksi dalam situasi yang khusus atau kongkret berbentuk prosedur, gagasan umum atau metodologi yang digeneralisasikan, ide-ide, prinsip teknis atau teori-teori yang harus diingat dan diterapkan. Juga bisa dikatakan pemahaman adalah tingkat kemampuan siswa memahami arti, konsep, situasi serta fakta yang diketahui, siswa tidak hanya hafal secara verbalitas, tapi memahami konsep dari masalah atau fakta yang dinyatakan, menyerap arti bahan materi yang dipelajari sehingga dapat mengingat kembali dan menginterprestasikan. 
Cybernetics: Journal of Research and Educational Studies

Volume 2 Nomor 3, Juli 2021

Halaman 84-93

\section{b. Pengertian Bentuk Aljabar}

Aljabar berasal dari bahasa arab "al-jabar" yang berarti "Pertemuan", "Hubungan" adalah cabang matematika yang dapat dicirikan sebagai generalisasi dari bidang Aritmatika. Aljabar juga merupakan nama sebuah struktur aljabar abstrak, yaitu aljabar dalam sebuah bidang.

Huruf-huruf dalam aljabar digunakan sebagai pengganti angka. Bentuk aljabar sering melibatkan angka (disebut Konstanta), huruf (disebut Peubah atau Variabel), dan operasi hitung. Hal ini penting untuk kita ketahui dan mengerti agar penulisan singkat dalam aljabar dapat kita gunakan untuk menyelesaikan masalah sehingga lebih mudah dipahami.

\section{c. Pengertian Hasil Belajar Matematika}

Belajar adalah suatu proses yang kompleks yang terjadi pada semua orang dan berlangsung seumur hidup, sejak dia masih bayi hingga ke liang lahat nanti. Belajar juga dapat diartikan sebagai suatu proses usaha yang dilakukan seseorang untuk memperoleh perubahan tingkah laku yang baru secara keseluruhan, sebagai hasil pengalaman sendiri dan interaksi lingkungannya. Perubahan tingkah laku tersebut menyembut perubahan yang bersifat pengetahuan (kognitif), keterampilan (psikomotorik) dan perubahan yang menyangkut nilai dan sikap (afektif). Belajar juga berarti perbaikan dalam tingkah laku dan kecakapan-kecakapan (manusia) atau memperoleh kecakapankecakapan tingkah laku yang baru.

Hasil belajar adalah kemampuan yang diperoleh anak setelah melalui kegiatan belajar. Belajar itu sendiri merupakan suatu proses dari seseorang yang berusaha untuk memperoleh suatu bentuk perubahan perilaku yang relatif menetap. Anak yang berhasil dalam belajar adalah yang berhasil mencapai tujuan-tujuan pembelajaran atau tujuan-tujuan intruksional.

\section{d. Hasil Belajar Matematika Pada Bentuk Aljabar}

Hasil belajar matematika adalah dapat membuat seorang anak berhasil dalam belajar yang berhasil mencapai tujuan-tujuan pembelajaran atau tujuantujuan interaksional. Hasil belajar yang ditunjukkan oleh siswa dapat menunjukkan kesulitan-kesulitan yang dialami oleh siswa. Kesulitan belajar yang dialami oleh siswa biasanya nampak dari kekeliruan-kekeliruan yang dilakukan oleh siswa ketika proses belajar. Contohnya pada mengerjakan soalsoal latihan yang ada pada buku matematika kelas VII yaitu mengenai operasi bentuk aljabar.

Kajian standar isi pada pelajaran semester ganjil dan semester genap di MTs yaitu :

a. Bilangan 
Cybernetics: Journal of Research and Educational Studies

Volume 2 Nomor 3, Juli 2021

Halaman 84-93

- Memahami sifat-sifat operasi hitung bilangan dan penggunaannya dalam pemecahan masalah.

b. Aljabar

- Memahami bentuk aljabar, persamaaan dan pertidaksamaan linier satu variabel.

- Menggunakan bentuk aljabar, persamaan dan pertidaksamaan linier satu variabel, dan perbandingan dalam pemecahan masalah.

- Menggunakan konsep himpunan dan diagram Venn dalam pemecahan masalah.

c. Geometri

- Memahami hubungan garis dengan garis, garis dengan sudut, sudut dengan sudut, serta menentukan ukurannya.

- Memahami konsep segi empat dan segitiga serta menentukan ukurannya.

\section{Materi Pokok Bahasan Bentuk Aljabar}

a. Pengertian Faktor Perkalian

Pada pembahasan tentang faktor bilangan cacah dinyatakan bahwa $14=2$ x 7, maka 2 dan 7 disebut faktor dari 14. Pengertian ini akan kita pakai sebagai dasar untuk membahas faktor perkalian dari suatu bentuk aljabar. Bentuk aljabar $3 a=3 x a$, maka $3 a$ memiliki faktor-faktor, yaitu 3 dan $a$. Faktor 3 disebut faktor angka atau faktor numerik. Faktor ini sering disebut juga koefisien dari $a$. Faktor $a$ disebut faktor huruf atau faktor alfabetik. Agar lebih mengerti, perhatikan contoh-contoh berikut .

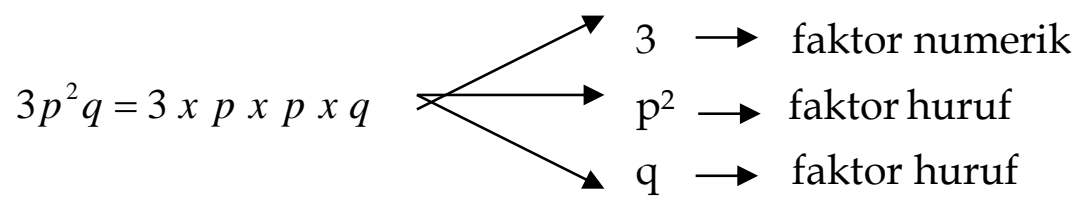

Jadi, faktor dari $3 \mathrm{p}^{2} \mathrm{q}$ adalah $3, \mathrm{p}^{2}$, dan $\mathrm{q}$. Pada $\mathrm{p}^{2}$, bilangan 2 disebut pangkat atau eksponen.

numerik

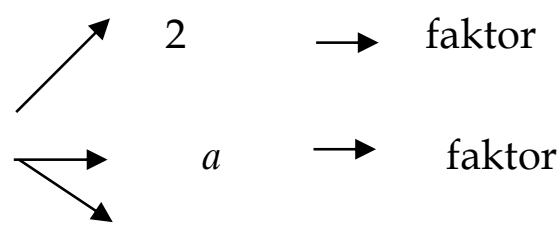

huruf

$$
2 a(b+3 \mathrm{c})=2 \times a \times(\mathrm{b}+3 \mathrm{c})
$$

$(\mathrm{b}+3 \mathrm{c}) \rightarrow$ faktor

aljabar 
Jadi, faktor $2 a(b+3 c)$ adalah $2, a$, dan $(b+3 c)$.

\section{b. Pengertian Suku dan Suku Sejenis}

Perhatikan bentuk-bentuk aljabar $3 a^{2}+6 a$ dan $6 p-8$. Dalam hal ini $3 a^{2}$ dan $6 a$ disebut suku-suku dari $3 a^{2}+6 a$ dan $6 p$ dan -8 disebut suku-suku dari $6 p-8$. Suku-suku dalam bentuk bentuk aljabar $6 \mathrm{x}-7 \mathrm{y}-3 \mathrm{z}$ misalnya, dapat diubah ke bentuk $6 x+(-7 y)+3 z$. Dengan demikian, suku-suku dari $6 x+(-7 y)+$ $3 z$ adalah $6 x,-7 y$, dan $3 z$.

Sekarang perhatikan bentuk-bentuk aljabar $3 a, 4 a+7 b$, dan $3 p-2 q-r$. bentuk-bentuk tersebut terturut-turut disebut suku tunggal, suku dua, dan suku tiga. Pemberian nama ini bersesuaian dengan banyak suku bentuk-bentuk aljabar tersebut. Bentuk aljabar $4 x+3 a+6 x$ mempunyai suku-suku $4 x, 3 a$, dan 6x. Suku-suku $4 x$ dan 6x memuat variabel yang sama, yaitu $x$. Suku-suku tersebut diberikan nama suku-suku sejenis, sedangkan $4 \mathrm{x}$ dan $3 a$ disebut sukusuku tidak sejenis.

\section{c. Pengertian Koefisien dan Konstanta}

Perhatikan bentuk aljabar $3 a^{4}+6 a^{3}+5 a^{2}+7 a+8$. Bilangan-bilangan 3,6,5,7 dan 8 disebut koefisien dari bentuk aljabar. Dalam hal dapat diterangkan sebagai berikut :

$$
\begin{array}{llll}
3 a^{4} \text { mempunyai koefisien } 3 & 7 a \text { mempunyai koefisien } 7 \\
6 a^{3} \text { mempunyai koefisien } 6 & 8 & \text { merupakan konstanta } \\
5 a^{2} \text { mempunyai koefisien } 5 & &
\end{array}
$$

\section{Faktor yang mempengaruhi Balajar}

\section{a. Faktor-Faktor Internal}

Faktor internal adalah semua faktor yang timbul dari luar diri anak itu sendiri, baik yang berkenan dengan segi jasmani anak maupun dengan segi rohani anak.

\section{b. Faktor-Faktor Eksternal}

Faktor eksternal adalah faktor yang bersumber dari luar diri anak didik, faktor ini disebut juga dengan faktor lingkungan. 
Cybernetics: Journal of Research and Educational Studies

Volume 2 Nomor 3, Juli 2021

Halaman 84-93

\section{KESIMPULAN}

1. Setelah dikonsultasikan dengan predikat pemahaman konsep bentuk aljabar siswa diatas maka pemahaman konsep bentuk aljabar siswa di kelas VII MTsN 2 Medan Tahun Ajaran 2019/2020 dapat digolongkan bahwa 3,06\% termasuk dalam katagori sangat kurang baik. Dari sudut ini sebenarnya secara umum siswa sekolah ini telah mempunyai pemahaman konsep bentuk aljabar siswa, sehingga mempunyai potensi untuk aktif, ulet, sedia, sabar dan disiplin mengikuti aktifitas belajar matematika di sekolah. Namun perlu mendapatkan perhatian, bahwa selain data ditemukan pula jumlah 31,53\% tergolong kurang pemahaman atau belum mempunyai pemahaman untuk belajar.

2. Hasil belajar siswa yang dicapai siswa disekolah ini dapat digolongkan bahwa siswa yang prestasinya tinggi adalah 26 orang atau 33,33\%, cukup 43 orang atau $55,13 \%$ kurang 8 orang atau $10,26 \%$ dan rendah 1 orang atau $1,28 \%$. Untuk kategori tinggi yaitu siswa memiliki skor 10-14, sedangkan untuk kategori cukup yaitu siswa memiliki skor 4 ke bawah.

3. Ditemukan adanya hubungan yang positif antara pemahaman konsep belajar dan hasil belajar matematika pada siswa kelas VII MTsN 2 Medan. Hal ini dapat dilihat dari perhitungan yang diperoleh, yaitu nilai $t_{\text {hitung }}=$ 37,48 , sedangkan nilai ttabel pada taraf signifikan $\alpha=0,05$ dengan derajat kebebasan $=n-2=78-276, t_{\text {tabel }}=1,990$. Sehingga diperoleh $t_{\text {hitung }}=37,48$ $>t_{\text {tabel }}=1,990$. Demikian Ho ditolak dan Ha diterima yang menyatakan bahwa ada hubungan yang signifikan antara pemahaman konsep bentuk aljabar dengan hasil belajar matematika siswa.

\section{DAFTAR PUSTAKA}

Ali Imron, Belajar E Pembelajaran, Jakarta : Pustaka Jaya, 1996.

Irma Fitria Amalia, Model Pembelajaran Kooperatif Teknik Think-Pair-Share Untuk Meningkatkan Pemahaman Konsep Fisika Siswa, Bandung : Skripsi Pada FPMIPA UPI, 2008.

Mulyono Abdurrahman, Pendidikan Bagi Anak Berkesulitan Belajar, Jakarta : Rineka Cipta, 1999.

Nana Sudjana, Penilaian Hasil Proses Belajar Mengajar, Bandung : Remaja Rosdakarya, 2005.

Pusat Bahasa Departemen Pendidikan Nasional, Kamus Besar Bahasa Indonesia, Jakarta : Balai Pustaka, 2005.

Pusat Bahasa Departemen Pendidikan Nasional, Kamus Besar Bahasa Indonesia, Jakarta : Balai Pustaka, 2001, Edisi Ketiga.

Sardiman, Media Pendidikan, Jakarta : Rajawali Pers, 1999. 
Cybernetics: Journal of Research and Educational Studies

Volume 2 Nomor 3, Juli 2021

Halaman 84-93

Slameto, Belajar dan Faktor-Faktor yang Mempengaruhinya, Jakarta : Rineka Cipta, 2002.

W. James Popham dan Eva L. Baker, Teknik Mengajar Secara Sistematis, Jakarta : Rineka Cipta, 2003.

W.S. Winkel, Psikologi Pengajaran, Yogyakarta : Media Abadi, 2004. 